\title{
Stylized Facts on the Interaction between Income Distribution and the Great Recession
}

\author{
Karl Aiginger ${ }^{1, *} \&$ Alois Guger ${ }^{1}$ \\ ${ }^{1}$ Austrian Institute of Economic Research WIFO, Arsenal Objekt 20, 1030 Vienna, Austria \\ *Corresponding author: Austrian Institute of Economic Research WIFO (director), Arsenal \\ Objekt 20, 1030 Vienna, Austria. Tel: 43-1-798-2601-210. E-mail: Karl.Aiginger@wifo.ac.at
}

Received: June 2, 2014 Accepted: July 15, $2014 \quad$ Published: September 8, 2014

doi:10.5296/rae.v6i3.5732 URL: http://dx.doi.org/10.5296/rae.v6i3.5732

\begin{abstract}
There are several narratives connecting the financial crisis - as well as the Great Depression of the 1930s - with the functional or personal income distribution and its pre-crisis movements. The paper investigates whether this claim can be supported with evidence showing that the crisis was deeper in countries in which incomes were more polarized or where wage shares were lower. Empirical evidence for 37 mainly industrialized countries does not generally support the hypothesis that either the level of or the change in distribution was closely linked to the performance of a country during the crisis. Some evidence shows a tentatively improved performance if wage shares as well as polarization decreased. Declining wage shares could have increased the resilience of firms in the crisis; the lower income differences may have bolstered consumption of domestic goods. The existence of more compelling evidence for the impact of distribution on the crisis may have been diluted by the global character of economies. Savings in one country or region can lead to low interest rates as well as financial or real investment in other regions via international capital flows which might stop abruptly in the crisis.
\end{abstract}

Keywords: Income distribution, wage shares, financial crisis, great recession, anti crisis strategies 


\section{Object and outline of the paper}

This paper investigates whether there is a relationship between the depth of the financial crisis across countries and income distribution (or its change) during the phase in the run up to the crisis. We use a sample of 37 mainly industrialized countries. There is a growing pool of literature depicting how the performance of countries in the crisis differed widely - with some countries experiencing no loss in GDP, whilst others have lost one fifth of their output (Aiginger, 2010A, 2011). Literature also exists analyzing how labor markets performed differently in the crisis. However, as far as income distribution is concerned the assertion is primarily that declining wage rates or the increasing polarization of incomes contributed to the crisis (similar claims exist for the Great Depression in the 30s of the last century). However up until now there have been very few investigations into whether the cross-country differences in functional or personal income distribution (or its change) were reflected in the depth of the crisis in individual countries.

The paper is structured in the following way. In the next section we outline hypotheses about how the changes in income distribution over the past one or two decades may have contributed to the financial crisis and what evidence has been presented so far on this point. In section 3 we introduce the data we use. We define "output performance" by aggregating quarterly and annual data on GDP into one indicator. Similarly we aggregate different aspects of income distribution into two indicators, one indicator for the "distribution level" and another for the "distribution change". The next section presents the main stylized facts. Then we test robustness using single indicators instead of the Principal Component Indicators for the distribution variables. And we add control variables, which have proved themselves to be relevant in studies explaining the output performance of countries in the crisis. We finally discuss how distribution could still have contributed to the crisis even if this impact is not reflected in cross-country evidence and then we conclude.

\section{Hypothesis on the connection between income distribution and the Financial Crisis}

A "classical" assertion that rising inequality in the US was a crucial factor in the Great Depression of the thirties comes from Galbraith (1997; first published in 1954). After rejecting some of the standard explanations for the Great Depression Galbraith named five weaknesses that made the economy in the twenties "profoundly unsound". As his first weakness he lists a "bad" distribution of income; "the rich were indubitably rich". Therefore the economy depended on investment and luxury consumption, both of which fluctuated widely (by contrast to traditional consumption goods).(Note 1) This argument thus stresses that inequality increases volatility since it favors demand components with large amplitudes.

Another reason why income dispersion may lead to a crisis stems from a variant of the underconsumption or underinvestment hypothesis. With increasing productivity and stagnating wages, the wage share falls and firms would have to invest progressively in physical capital in order to prevent effective demand from falling below supply. Additionally the higher the polarization of incomes the more consumption decreases out of a given income 
(since consumption as a share of income decreases for higher incomes).

Several authors follow one of these three lines when explaining the financial crisis. Stiglitz (2009) claims that money had gone from those who would spend it to those who are so well off that "try as they might they cannot spend it". Floods of liquidity (from abroad or from the rich) then lead to reckless leverage and risks. Fitoussi - Stiglitz (2009) also refer to rising inequality in many countries but connect this with asymmetric globalization (greater liberalization of capital relative to labor markets). Fitoussi - Saraceno (2010) blame increasing inequality (over decades) for slow growth in demand, which had to be countered by expansionary monetary policy, which then led to a high return on investment for people profiting from redistribution (and the expectation that increasing asset prices were sustainable).

Rajan (2010) directly links increasing inequality and stagnating wages with the political pressure on Fannie Mae and Freddi Mac to provide cheap credit coupled with loose supervision for low-income people in the US. If wages were not increased but low-income earners aspired to higher standards of living, low interest rates were a politically accepted solution. Improving education would be preferable in the longer run, while offering cheap credit was attractive in the short run and maximized votes. Van Treeck (2012) argues along the same line, stating that the incomes of low-income earners were stagnating, but their aspirations were not. Atkinson (1997) calls this a variant of relative income hypothesis (people desire those things already possessed by the rich). For similar arguments see also Horn et al. (2009).

Stockhammer (2011) argues that the financial crisis has been the result of the interaction of the deregulation of the financial sector and the polarization of income distribution. Income distribution had shifted to the disadvantage of wages (by approximately 10 percentage points) in many continental European countries in the pre-crisis period, while the polarization of individual incomes had been more prominent in the Anglo-Saxon countries. Some statistical facts may bridge this difference: the polarization of individual incomes originated to a large degree from the extra high incomes of managers, if these would be added to profits the labor share would fall also in the UK and the US. A consequence of income polarization would have been decreased consumer demand, which would ceteris paribus then have reduced aggregate demand. In some countries (debt-led economies) policies to mitigate this drag were to foster credit (credit driven growth), in others (export-led economies) it was boosting exports (Germany). Credits were encouraged by financial deregulation, and supported by property bubbles and capital inflow from countries with export surpluses (Stockhammer, 2011); we could also add lower interest rates due to European integration (specifically in peripheral countries), financial market innovations or increasing government deficits as other strategies to counteract falling consumer demand. According to Stockhammer(Note 2) rising inequality and/or wage suppression is not only an important cause for economic crises but also a cause for higher GDP losses in a crisis: In debt-led economies higher inequality deepens a crisis due to higher household leverages. And, export-led countries although they start rather comfortably with trade surpluses will have to face the repercussions of their trading partners running trade deficits which have to reduce import demand. 
Some authors analyzing the causes of the crisis in the US refer to the specific policy reaction of the US government, which is characterized by Kumhof - Ranciere (2010,) as increasing incomes for the rich and the leverage for the poor. In Europe, Spain and Iceland experienced property bubbles too, not so much stimulated by specific economic policies addressing low income earners, but as consequence of the capital abundance in banks and low interest rates. Interest rates were specifically low in southern European countries (Italy, Greece and Spain) after the introduction of the Euro, as compared to historically high inflation and nominal interest rates.

We mentioned already that other countries stabilized aggregate demand by increasing export surpluses (Germany, Austria, and the Netherlands). Economic policy supported this specifically in Germany by restraining wages and deregulating the labor market (e.g. by the so-called Hartz measures), and conditioning unemployment payments on the acceptance of very low paid jobs.

Palley (2011) does not list distribution as a cause of the financial crisis, but sees the main culprit of the crisis as the regime change of economic policy in the US: it changed from stabilizing the labor market to combating inflation and stabilizing the financial markets (after deregulation). Cheep credit policies for homeowners were needed (and property bubbles followed) to prevent economic growth from fading out.

More skeptical - as far as distribution being seen as a cause of a crisis - are Acemoglu (2011) and Atkinson - Morelli (2011). Atkinson -Morelli stress that the rise in inequality before 2007 was not reflected in consumption inequality and that poverty rates and the Gini measure of household income distribution increased only very moderately in the ten years before the crisis. Analysts should also distinguish between the issue of whether the "level" of inequality or its "rise" should be seen as a cause of the crisis. Further we should distinguish between inequality as a "cause" of the crisis from the possibility that rising inequality and the crisis were both jointly caused by third factors ("co-determination"). It could be that asset bubbles and performance payments for managers were the causes of inequality and of the crisis. This is supported by data showing that one of the forces of rising inequality was the skyrocketing of the very high incomes (top 1\%) and these were, to a large extent, determined by asset prices and performance pay schedules (bonuses). Atkinson et al. stress furthermore that data were collected more with an eye on comparability over time and not across countries, limiting the testing of the "level" of income hypotheses. Collecting evidence on two data sets (one for 24, the second for 36 crises), he found that inequality increased before consumption dropped in only 9 cases (out of 36 cases; with 2 falling, 15 stable, 10 not classifiable) and also in nine of 24 GDP collapses. Thus only limited support for the hypothesis that increases in inequality led to the crisis exist, if a "smoking gun is found it is only in a third of the cases". Bordo and Messner (2011) also reject that income distribution led to credit booms and a financial crisis. Low interest rates and economic expansions are the only two robust determinants of credit booms in their data set.

Another line of literature investigates the effect of the crisis on poverty and income distribution (reverse causality). Since real time data for the consequences of the crisis on 
distribution and poverty are still rare, Habib et al. (2010) use simulations. These show the predicted increase in poverty and income polarization, with some interesting features: a crisis impacts more on skilled and rural individuals than on the chronically poor.

Summarizing this section, there are many theoretical lines "connecting" the crisis to faltering demand due to increasing inequality. Rising inequality may come from a decreasing wage share or from larger polarization within wages. Other theories stress the causal effect of policy reactions which stabilized growth in the short run but destabilized it in the longer run. Policy reactions to stabilize growth in a period of under-investment or under-consumption included expansionary monetary policy encouraging cheap credit or liberalization leading to new financial products. Foreign trade inequilibria were mounting, since they were not reduced by allowing currencies to appreciate (China vs. US) or were even fostered by export led strategies (Germany). Wage increases below productivity and specifically the wages of the lowest third encouraged policy reactions which channeled cheap credits also to the poor population (instead of increasing wages or reducing unemployment). In some European countries similar trends were seen but with a focus on deregulating part-time and irregular contracts, or by cheap credits in countries with a history of inflation and high interest rates.

On the empirical side we found no single cross country study relating the depth of the crisis with the level of or the change in income distribution before the crisis. This gap in the literature holds true also for falling wage shares as well as the increasing polarization of household incomes. Atkinson's explanation that distribution data were gathered with an eye on comparability over time (and across countries) might be one reason for this.

\section{The data used and the method to extract a maximum of information}

\subsection{The Sample}

Our sample covers 37 European and non-European industrialized countries including Turkey and Mexico, China and India (even if for the latter some data on income distribution are not available).

\subsection{The depth of the crisis}

The depth of the crisis is measured by the drop in GDP between 2007 and 2010 using different transformations and combining them following Aiginger (2011) via Principal Component Analysis into one indicator (PC-Output).

We use the same technique to extract one variable for the income distribution level at the start of the financial crisis and a second one for changes in income distribution. By using the Principal Component Technique we maximize the informational content while keeping the analysis simple.

The output performance is derived from the following four indicators:

The rate of change of real GDP in 2009; 
The cumulated change over the three years 2008, 2009, 2010;

The decrease of quarterly GDP from the pre-crisis peak to the in-crisis trough;

The actual growth of real GDP in the three years 2008, 2009, 2010 relative to the "pre-crisis" growth from 2000 to 2007 ("trend change").

For the income distribution level (PC-DISTR-L) we use three measures of the inequality of personal incomes (polarization) and two measures indicating the wage share (in aggregate income).

The Gini coefficient measures the income(Note 3) differences between all households, being zero if they all have the same income and being one if there is maximum inequality. For the "pre-crisis distribution level" we use data for 2005.

The poverty rate measures the share of people with incomes less than $60 \%$ of the median income; its pre-crisis value is for the "mid 2000s".

The inter-quintile ratio relates the incomes of the top $20 \%$ to those of the low $20 \%$ in the mid 2000s.

The wage share is wages in total incomes for 2007.

The adjusted wage share corrects for changes in the number of employed people, data are taken for the year 2007.

Thus all these five indicators are taken for a pre-crisis year to derive a "level" of income indicator.

Then we construct a second indicator to measure the "change" in income distribution (PC-DISTR-C) in a period of ten to twenty years before the crisis. For the Gini we used the change between the "mid 2000s" and the "mid eighties". For the poverty rate and the inter-quintile ratio we take the change towards the "mid nineties" and for wage shares the change between 1995 and 2007. Most of these choices were due to data availability. Especially for wage shares annual data over a longer span are available (and tested alternatively), but in principle we thought that a time span of ten to twelve years would be a good choice since it is longer than a typical business cycle. (Note 4)

We used Principal Component Analysis (PC) to extract maximum information and minimum redundancy in constructing the indicator on the level of income distribution (PC-DISTR-L) as well as the indicator for change (PC-DISTR-C). Each Principal Component Indicator is quantitative, technically restricted to the lie between zero and a hundred. For illustration's sake we sometimes use ranks to show whether performance ranks and distribution ranks fit together (for levels and changes of the latter). 
Table 1. The output performance during the Great Recession ( $\mathrm{PC}$ and its four components)

\begin{tabular}{|c|c|c|c|c|c|c|}
\hline & \multicolumn{2}{|c|}{ PC Output performance ${ }^{1}$} & \multirow[t]{2}{*}{ GDP change 2009} & $\begin{array}{l}\text { GDP change } \\
2010-2007\end{array}$ & \multirow{2}{*}{$\begin{array}{l}\text { Quarterly drop } \\
\text { from peak to } \\
\text { trough }^{2}\end{array}$} & \multirow[t]{2}{*}{ Trend change $^{3}$} \\
\hline & Value & Rank & & & & \\
\hline China & 97 & 1 & 9.2 & 32.2 & 9.24 & -1.4 \\
\hline India & 94 & 2 & 7.6 & 25.4 & 7.64 & -0.1 \\
\hline Poland & 76 & 3 & 1.6 & 11.0 & 1.64 & -0.6 \\
\hline Australia & 71 & 4 & 1.2 & 5.5 & 1.24 & -1.4 \\
\hline Korea & 71 & 5 & 0.3 & 8.9 & 0.34 & -1.5 \\
\hline Switzerland & 66 & 6 & -1.9 & 2.9 & -2.4 & -0.7 \\
\hline Canada & 65 & 7 & -2.8 & 1.0 & 1.44 & -1.5 \\
\hline New Zealand & 64 & 8 & -0.4 & 0.7 & -0.4 & -2.3 \\
\hline Norway & 63 & 9 & -1.7 & -0.6 & -2.4 & -1.4 \\
\hline Belgium & 61 & 10 & -2.8 & 0.3 & -4.1 & -1.3 \\
\hline Top 10 in PC Output ${ }^{5}$ & 73 & 6 & 1.0 & 8.7 & 1.24 & -1.2 \\
\hline Greece & 47 & 28 & -3.2 & -6.8 & -3.2 & -7.2 \\
\hline Hungary & 47 & 29 & -6.8 & -4.8 & -7.9 & -4.1 \\
\hline Finland & 47 & 30 & -8.2 & $-\quad 3.9$ & -9.1 & -3.2 \\
\hline Romania & 46 & 31 & -6.6 & -1.6 & -6.6 & -5.7 \\
\hline Slovenia & 44 & 32 & -8.0 & $-\quad 3.4$ & -9.5 & -4.7 \\
\hline Iceland & 43 & 33 & -6.7 & -9.3 & -6.3 & -5.8 \\
\hline Ireland & 36 & 34 & -7.0 & -10.1 & -12.5 & -6.7 \\
\hline Lithuania & 20 & 35 & -14.8 & -11.1 & -18.1 & -8.6 \\
\hline Estonia & 16 & 36 & -14.3 & -15.5 & -19.6 & -9.4 \\
\hline Latvia & 0 & 37 & -17.7 & -20.7 & -26.1 & -12.0 \\
\hline Low 10 in PC Output ${ }^{5}$ & 34 & 33 & -9.3 & -8.7 & -11.9 & -6.7 \\
\hline All countries used & 55 & 19 & $-\quad 4.3$ & $-\quad 0.4$ & $-\quad 5.5$ & $-\quad 3.3$ \\
\hline
\end{tabular}

Source: Eurostat (AMECO, November 2011), Oxford Econometrics Forecasts, April 2012. - ${ }^{1}$ Overall indicator derived by Principal Component Analyses from four subindicators. - ${ }^{2}$ GDP decrease for 2011, 2012 not included. - ${ }^{3}$ 2010-2007 - 2007-2000. - ${ }^{4}$ No decrease in GDP. - ${ }^{5}$ Unweighted average.

\subsection{Stylized facts about output performance}

The crisis was very different across countries if measured by the drop in GDP. Taking the most volatile measure - the drop of output between the highest quarterly GDP before the crisis and the lowest quarterly GDP in the crisis - we find six countries in which output did not decrease (China, India, Canada, Australia, Korea, and Poland). On the other side of the spectrum, output dropped by more than $10 \%$ in Ireland, Estonia, Lithuania, and Latvia. (Note 5) On (unweighted) average, the quarterly output dropped by 5.5\% (see Table 1). Thus output decline was for world output, and for the sample of countries used in this paper far less than in the Great Depression in the nineteen twenties (Aiginger, 2010A).

Using the annual change of GDP in 2009 as an indicator for output performance we have five countries with increasing GDP, and three with drops of more than $10 \%$, the average was $4.3 \%$.

Trend changes occurred in all countries. For seven countries it was more than 5\%, for 14 countries it was less than $2 \%$, and only for India was it only $0.1 \%$.

\subsection{Stylized facts about labor shares}

The share of wages in total income decreased in the majority of countries, on average, 
however, only from $64 \%$ to $63 \%$ i.e. by less than one percentage point between 1995 and 2007. Drops by more than 5 percentage points occurred in nine countries, the highest drops being in Norway, Germany, Austria, Slovenia and Finland. Wage share increased in sixteen countries, the highest increases being in Iceland, Greece and Portugal (around and more than $7 \%$ ). In the southern European countries wage share had been exceptionally low in 1995 whereas it was high in Iceland before the crisis. (Note 6)

If we take wage shares adjusted by employment changes we find that the adjusted wage share increased in the twelve years preceding the crisis; on average from $64 \%$ to $65.5 \%$. It decreased strongly for the same countries (Norway, Germany, Austria) as unadjusted wage shares and increased specifically for Iceland, Greece, Portugal, Spain and Turkey.

\subsection{Stylized facts about polarization}

Poverty rose from $17 \%$ to $17.5 \%$ between the mid 1990 s and the mid 2000 s; increases above three percentage points occurred in Sweden and Finland where it was very low in the nineties and in Estonia, Korea and New Zealand.

The Gini coefficient increased from 0.28 to 0.31 . This is the indicator signaling the strongest polarization. Nevertheless there are eight countries in which the Gini decreased between the mid 1980s and 2005; Turkey, Korea, Ireland, Spain, Greece (from high inequality positions) and in Switzerland, France and Belgium (from moderate positions).

The inter-quintile ratio is about 5.3 indicating that the top 20\% earned more than five times the income of the lower $20 \%$ and is marginally declining (about 0.1 percentage points). The largest increases are shown for the US and Canada, Finland, Germany and Austria. Decreases were strong in Mexico, the UK and Greece, all countries in which inequality according to this measure was high in the 1990s.

\section{The relationship between output performance and distribution}

The first outcomes were disappointing showing no evidence of any correlation between a country's level of output performance during the crisis and the level of income distribution (PC-DISTR-L) at its start. The results for the impact of changes in the distribution in the period preceding the crisis (PC-DISTR-C) are not close either, but some pattern can be detected.

\subsection{Correlations and stylized facts about output performance and the level of inequality}

Correlating the PC-Output with the PC distribution level produces no single significant result; the correlation coefficient between the output performance and the level of distribution indicator is 0.08 , it is even less if we correlate the output performance with its individual components. It makes no difference if we delete outsiders, or correlate ranks instead of values (see Table 2). 


\section{Macrothink}

Research in Applied Economics

ISSN 1948-5433

2014, Vol. 6, No. 3

Table 2. The relations between output performance and distribution (level, change; overall and components)

\begin{tabular}{|c|c|c|}
\hline & \multicolumn{2}{|c|}{ Values } \\
\hline & Level & Change \\
\hline PC distribution & 0.08 & -0.05 \\
\hline Gini & 0.08 & $-0.33 x x$ \\
\hline Poverty rate & 0.05 & 0.06 \\
\hline Interquintile ratio & 0.07 & -0.01 \\
\hline Wage share $^{1}$ & -0.06 & -0.01 \\
\hline Wage share adjusted ${ }^{1}$ & -0.06 & -0.01 \\
\hline Wage share long ${ }^{1}$ & & $-0.30 \mathrm{x}$ \\
\hline Wage share long adjusted ${ }^{1}$ & & $-0.34 \mathrm{xx}$ \\
\hline
\end{tabular}

${ }^{1}$ Remark: Minus implies that output performance better for lower wage share (more inequality). $\mathrm{x} \ldots t$-statistic at 5 percent level. $\mathrm{xx} \ldots$ $t$-statistic at 10 percent level.

\subsection{Worst performers in output}

To see why this is the case let us look first at the ten countries with the worst in-crisis output performances and then at the countries with the best in-crisis output performances.

The low performers during the financial crisis were (according to our output performance measure and in line with the literature) three peripheral European countries (Iceland, Ireland, and Greece), three Baltic countries (Latvia, Lithuania, Estonia) and three new EU member countries (Romania, Hungary and Slovenia) plus Finland. In these countries the GDP dropped by more than $10 \%$ during the crisis (if the crisis is seen as over).

Out of these low performing countries the Baltic countries, Greece and Ireland had high inequality at the start of the crisis, which would establish a relationship between income distribution and the depth of the crisis. However, Slovenia as well as Iceland had rather equal income distribution and Hungary and Finland - also two of the ten countries with low performance - had a very equal distribution (Finland excelled in low polarization and Hungary in high wage share). The average rank in output performance of the ten countries with the most unequal distribution in the mid 2000s was 18 (with small differences according to the four distribution indicators. 
Table 3. Output performance and distribution indicators

Ranked according to PC-Output

\begin{tabular}{|c|c|c|c|c|c|c|c|c|c|c|}
\hline & \multicolumn{2}{|c|}{ PC-Output } & \multicolumn{2}{|c|}{ PC-Distribution level } & \multicolumn{2}{|c|}{$\begin{array}{c}\text { PC-Distribution } \\
\text { change }\end{array}$} & \multicolumn{2}{|c|}{$\begin{array}{c}\text { Gini level } \\
2005 \\
\end{array}$} & \multicolumn{2}{|c|}{$\begin{array}{c}\text { Gini change } \\
2005 \text { vs. mid } 80\end{array}$} \\
\hline & Value & Rank & Value & Rank & Value & Rank & Value & Rank & Value & Rank \\
\hline China & 97 & 1 & 46 & 28 & 69 & 26 & 0.28 & 21 & 0.12 & 34 \\
\hline India & 94 & 2 & 41 & 20 & 63 & 17 & 0.32 & 29 & 0.02 & 13 \\
\hline Poland & 76 & 3 & 57 & 35 & 78 & 31 & 0.26 & 17 & 0.09 & 32 \\
\hline Australia & 71 & 4 & 39 & 18 & 63 & 18 & 0.31 & 26 & 0.01 & 9 \\
\hline Korea & 71 & 5 & 45 & 25 & 58 & 10 & 0.33 & 31 & -0.02 & 4 \\
\hline Switzerland & 66 & 6 & 23 & 6 & 58 & 8 & 0.31 & 25 & -0.03 & 3 \\
\hline Canada & 65 & 7 & 38 & 16 & 77 & 29 & 0.29 & 22 & 0.02 & 16 \\
\hline New Zealand & 64 & 8 & 48 & 30 & 69 & 25 & 0.27 & 18 & 0.06 & 28 \\
\hline Norway & 63 & 9 & 30 & 13 & 83 & 35 & 0.22 & 10 & 0.05 & 26 \\
\hline Belgium & 61 & 10 & 28 & 11 & 58 & 9 & 0.27 & 20 & 0.00 & 8 \\
\hline Top 10 in PC Output ${ }^{1}$ & 73 & 6 & 40 & 20 & 68 & 21 & 0.29 & 22 & 0.03 & 17 \\
\hline Greece & 47 & 28 & 51 & 33 & 38 & 3 & 0.34 & 32 & -0.02 & 6 \\
\hline Hungary & 47 & 29 & 21 & 4 & 62 & 16 & 0.22 & 8 & 0.07 & 31 \\
\hline Finland & 47 & 30 & 24 & 7 & 84 & 36 & 0.21 & 6 & 0.05 & 24 \\
\hline Romania & 46 & 31 & 50 & 31 & 58 & 11 & 0.20 & 3 & 0.12 & 35 \\
\hline Slovenia & 44 & 32 & 22 & 5 & 75 & 28 & 0.17 & 1 & 0.06 & 27 \\
\hline Iceland & 43 & 33 & 9 & 1 & 17 & 1 & 0.26 & 16 & 0.04 & 23 \\
\hline Ireland & 36 & 34 & 46 & 26 & 63 & 19 & 0.33 & 30 & -0.02 & 5 \\
\hline Lithuania & 20 & 35 & 44 & 24 & 66 & 22 & 0.22 & 7 & 0.12 & 36 \\
\hline Estonia & 16 & 36 & 46 & 27 & 81 & 33 & 0.23 & 12 & 0.11 & 33 \\
\hline Latvia & 0 & 37 & 41 & 19 & 79 & 32 & 0.23 & 13 & 0.13 & 37 \\
\hline Low 10 in PC Output ${ }^{1}$ & 34 & 33 & 35 & 18 & 62 & 20 & 0.24 & 13 & 0.07 & 26 \\
\hline All countries used & 55 & 19 & 39 & 18 & 64 & 19 & 0.28 & 19 & 0.04 & 19 \\
\hline
\end{tabular}

Source: Gini: OECD; The Standardized World Income Inequality Database. $-{ }^{1}$ Unweighted average.

Value: Value of Principle component, resp. Gini.

PC Distribution level: derived by Principle Components from five subindicators on level data.

PC Distribution change derived by Principle Components from five subindicators for changes in distribution.

Lower ranks for better Output performance, less polarization, decreasing inequality.

\subsection{Best performers in output do not excel in equality level}

The best performers during the crisis were China and India (for which no good data on distribution exist), then comes Poland, Korea, Switzerland, and three "liberal" OECD countries (Australia, Canada and New Zealand). Norway and Belgium complete the list of the ten top countries for output performance (PC-Output-L).

Poland has a rather unequal income distribution and a low wage share, the same holds true for Korea. Switzerland has medium inequality as far as individual incomes are concerned and a high wage share. Australia, Canada and New Zealand rank low at least with regards to personal income equality. Thus none of best ten performers in output (with the exception of Switzerland) belongs to the equality "champions". Even in the rankings of the individual indicators the top 10 places in output performance are scarce: Switzerland has a high wage share and low poverty. On average the top 10 performers as regards output were ranked in the 20s for the PC-distribution level (a rank similar to the rank of the lowest ten).

Given these stylized facts as well as the dichotomy between the top and bottom performers in 
output and their relationship with distribution, it comes as no surprise that there is a lack of any significant correlation. The reason for the poor correlation is that the top performers did not excel in income distribution at the start of the crisis, nor did those countries with less polarization. The low performers did not start from higher income differences or from lower wage rates. (Note 7)

\subsection{No correlations between output performance and overall change in equality}

If we correlate output performance with the overall indicator on distribution change the result is an even lower correlation. This is also true for the change in the poverty rate as well as the change in the inter-quintile ratio. The only significant result is that output performance correlates negatively with the change of the Gini coefficient $(\mathrm{R}=0.33$ which is significant at the $5 \%$ level).

Let us first look at the general indicator for change. Out of the top ten performers in output only two are among the top ten countries moving towards more equality, with Switzerland ranking eighth and Belgium ranking ninth. Canada, Poland and Norway are top output performers, which tipped in the direction of more inequality at least for some indicators. In Canada both wage shares fell, and all polarization indicators increased. For Poland and Norway four of the five indicators on equality dropped. The overall position of the top performers is 21 for equality to change, which is below the middle.

Out of the countries with a heavy crisis, Finland, the Baltic countries and Slovenia witnessed severe increases in polarization as well as drops in the wage share. The overall rank for the low performers is rank 20 , about the same as that as the top output performers indicating that the correlation coefficient cannot be different from zero.

\subsection{But output performance is better in countries with decreasing Gini...}

While output performance does not correlate with our overall indicator on changes in distribution, it is significantly related to the change of the Gini coefficient $(R=0.33$; significant at 5\% level) indicating better output performance in the crisis if the Gini decreased between 1985 and mid 2000s.

Again we examine the countries in search of an explanation. Six of the top 10 output performers have decreasing or stable Ginis (specifically Switzerland and Korea have decreasing ones). Secondly most of the low performers had increasing inequality as measured by the Gini. The average rank in Gini change was 17 for high performers and 26 for low performers, indicating how the significant correlation came about (see Table 3). 
Table 4. Performance ranked according to Gini change

\begin{tabular}{|c|c|c|c|c|c|c|c|c|c|c|}
\hline & \multicolumn{2}{|c|}{ PC-Output } & \multicolumn{4}{|c|}{ Gini } & \multicolumn{4}{|c|}{ Wage share } \\
\hline & \multirow[b]{2}{*}{ Value } & \multirow[b]{2}{*}{ Rank } & \multicolumn{2}{|c|}{ Level 2005} & \multicolumn{2}{|c|}{$\begin{array}{c}\text { Gini change } \\
2005 \text { vs. Mid } 80 \text { s }\end{array}$} & \multicolumn{2}{|c|}{ Level 2007} & \multicolumn{2}{|c|}{$\begin{array}{c}\text { Change } \\
2007 \text { vs. } 1985\end{array}$} \\
\hline & & & Value & Rank & Value & Rank & Value & Rank & Value & Rank \\
\hline Turkey & 59 & 12 & 0.41 & 36 & -0.05 & 1 & 24.7 & 37 & 8.3 & 5 \\
\hline Spain & 54 & 20 & 0.32 & 22 & -0.05 & 2 & 65.6 & 17 & 4.0 & 11 \\
\hline Switzerland & 66 & 6 & 0.28 & 10 & -0.03 & 3 & 75.2 & 3 & 5.7 & 8 \\
\hline Korea & 71 & 5 & 0.32 & 18 & -0.02 & 4 & 61.1 & 27 & 9.1 & 4 \\
\hline Ireland & 36 & 34 & 0.31 & 17 & -0.02 & 5 & 61.6 & 26 & -4.0 & 25 \\
\hline Greece & 47 & 28 & 0.32 & 23 & -0.02 & 6 & 47.7 & 34 & 5.2 & 9 \\
\hline France & 60 & 11 & 0.29 & 14 & -0.01 & 7 & 68.7 & 10 & -4.3 & 26 \\
\hline Belgium & 61 & 10 & 0.27 & 8 & 0.00 & 8 & 67.7 & 14 & -1.9 & 20 \\
\hline Australia & 71 & 4 & 0.32 & 18 & 0.01 & 9 & 69.6 & 8 & -2.4 & 24 \\
\hline Denmark & 53 & 24 & 0.23 & 1 & 0.01 & 10 & 78.6 & 2 & 3.5 & 12 \\
\hline Top 10 for Gini decline & 58 & 15 & 0.31 & 17 & -0.02 & 6 & 62.0 & 18 & 2.3 & 14 \\
\hline New Zealand & 64 & 8 & 0.34 & 26 & 0.06 & 28 & 64.3 & 21 & -5.5 & 27 \\
\hline Czech Republic & 54 & 21 & 0.26 & 6 & 0.06 & 29 & 62.3 & 25 & 7.0 & 7 \\
\hline Slovakia & 53 & 23 & 0.24 & 4 & 0.07 & 30 & 51.5 & 32 & -7.1 & 31 \\
\hline Hungary & 47 & 29 & 0.29 & 15 & 0.07 & 31 & 72.9 & 5 & -1.0 & 18 \\
\hline Poland & 76 & 3 & 0.35 & 30 & 0.09 & 32 & 50.0 & 33 & -5.9 & 28 \\
\hline Estonia & 16 & 36 & 0.34 & 27 & 0.11 & 33 & 66.5 & 15 & 1.0 & 15 \\
\hline China & 97 & 1 & 0.40 & 35 & 0.12 & 34 & 62.8 & 23 & -0.3 & 16 \\
\hline Romania & 46 & 31 & 0.32 & 21 & 0.12 & 35 & 44.6 & 35 & 4.5 & 10 \\
\hline Lithuania & 20 & 35 & 0.34 & 29 & 0.12 & 36 & 58.0 & 28 & 7.3 & 6 \\
\hline Latvia & 0 & 37 & 0.36 & 32 & 0.13 & 37 & 65.4 & 18 & 16.9 & 1 \\
\hline Low 10 for Gini decline & 47 & 22 & 0.32 & 23 & 0.10 & 33 & 59.8 & 24 & 1.7 & 16 \\
\hline All countries used & 55 & 19 & 0.31 & 19 & 0.04 & 19 & 62.8 & 23 & -0.3 & 19 \\
\hline
\end{tabular}

Source: Wage share: Eurostat (AMECO); Gini: OECD; The Standardized World Income Inequality Database.

Lower ranks for better Output performance, less polarization, decreasing inequality.

\section{6 ... and worse for countries with increasing long run wage shares}

The correlation between distribution change and wage ratio is inconclusive if we measure changes in the wage ratio between 2007 and 1995. If we extend the period for which the change is measured to be from 1985, the correlation becomes significant and negative. This implies that in countries in which the share of wages was falling, output performance was better. This relationship is bolstered on the one hand by the fact that 6 out of the top 10 countries in output performance had decreasing wage shares (Norway, Poland, New Zealand, Australia, Canada, Belgium), and only two of the top countries had increasing wage shares. On the other hand several low performers including some of the southern peripheral countries had increasing wage shares (Greece, Romania, Latvia, Spain, and Estonia; see Table 4 and Table 5). 
Table 5. Performance ranked according to change of long run wage shares

\begin{tabular}{|c|c|c|c|c|c|c|c|c|c|c|}
\hline & \multicolumn{2}{|c|}{ PC-Output } & \multicolumn{4}{|c|}{ Gini } & \multicolumn{4}{|c|}{ Wage share } \\
\hline & \multirow[b]{2}{*}{ Value } & \multirow[b]{2}{*}{ Rank } & \multicolumn{2}{|c|}{ Level 2005} & \multicolumn{2}{|c|}{$\begin{array}{l}\text { Gini change } 2005 \\
\text { vs. Mid 80s }\end{array}$} & \multicolumn{2}{|c|}{ Level 2007} & \multicolumn{2}{|c|}{$\begin{array}{c}\text { Change } \\
2007 \text { vs. } 1985\end{array}$} \\
\hline & & & Value & Rank & Value & Rank & Value & Rank & Value & Rank \\
\hline Latvia & 0 & 37 & 0.36 & 32 & 0.13 & 37 & 65.4 & 18 & 16.9 & 1 \\
\hline Iceland & 43 & 33 & 0.30 & 16 & 0.04 & 23 & 93.1 & 1 & 11.5 & 2 \\
\hline Portugal & 59 & 15 & 0.39 & 34 & 0.03 & 18 & 73.1 & 4 & 9.3 & 3 \\
\hline Korea & 71 & 5 & 0.32 & 18 & -0.02 & 4 & 61.1 & 27 & 9.1 & 4 \\
\hline Turkey & 59 & 12 & 0.41 & 36 & -0.05 & 1 & 24.7 & 37 & 8.3 & 5 \\
\hline Lithuania & 20 & 35 & 0.34 & 29 & 0.12 & 36 & 58.0 & 28 & 7.3 & 6 \\
\hline Czech Republic & 54 & 21 & 0.26 & 6 & 0.06 & 29 & 62.3 & 25 & 7.0 & 7 \\
\hline Switzerland & 66 & 6 & 0.28 & 10 & -0.03 & 3 & 75.2 & 3 & 5.7 & 8 \\
\hline Greece & 47 & 28 & 0.32 & 23 & -0.02 & 6 & 47.7 & 34 & 5.2 & 9 \\
\hline Romania & 46 & 31 & 0.32 & 21 & 0.12 & 35 & 44.6 & 35 & 4.5 & 10 \\
\hline Top 10 increasing wage share & 46 & 22 & 0.33 & 23 & 0.04 & 19 & 60.5 & 21 & 8.5 & 6 \\
\hline Poland & 76 & 3 & 0.35 & 30 & 0.09 & 32 & 50.0 & 33 & -5.9 & 28 \\
\hline Mexico & 58 & 17 & 0.47 & 37 & 0.02 & 14 & 35.0 & 36 & -6.6 & 29 \\
\hline United Kingdom & 52 & 25 & 0.33 & 25 & 0.02 & 15 & 68.3 & 12 & -6.8 & 30 \\
\hline Slovakia & 53 & 23 & 0.24 & 4 & 0.07 & 30 & 51.5 & 32 & -7.1 & 31 \\
\hline Norway & 63 & 9 & 0.28 & 10 & 0.05 & 26 & 56.9 & 30 & -7.3 & 32 \\
\hline Germany & 58 & 18 & 0.29 & 13 & 0.03 & 19 & 63.3 & 22 & -7.8 & 33 \\
\hline Austria & 59 & 13 & 0.27 & 7 & 0.03 & 17 & 65.6 & 16 & -8.0 & 34 \\
\hline Slovenia & 44 & 32 & 0.23 & 2 & 0.06 & 27 & 70.6 & 7 & -8.8 & 35 \\
\hline Sweden & 55 & 19 & 0.23 & 3 & 0.04 & 20 & 71.6 & 6 & -10.7 & 36 \\
\hline Finland & 47 & 30 & 0.25 & 5 & 0.05 & 24 & 65.0 & 19 & -11.8 & 37 \\
\hline Low 10 increasing wage share & 56 & 19 & 0.29 & 14 & 0.05 & 22 & 59.8 & 21 & -8.1 & 33 \\
\hline All countries used & 55 & 19 & 0.31 & 19 & 0.04 & 19 & 62.8 & 23 & -0.3 & 19 \\
\hline
\end{tabular}

Source: Wage share: Eurostat (AMECO); Gini: OECD.

Lower ranks for better Output performance, less polarization, decreasing inequality.

The result that in crisis performance of countries was better for countries in which wage shares decreased (or did not increase) is a very tentative one. First it only became evident for the period from 1985-2007, and did not exist for the shorter period of changes in wage share between 1995 and 2007. Secondly it may hide the true causality. In countries with structural problems and shifts in global competiveness e.g. by the entry of emerging countries into traditional markets, output growth will be slow, and given some resilience of employment and wages, wage share will increase. This again lowers competitiveness and this will be brutally revealed in a general crisis. For the peripheral countries in Europe this is described as disequilibria or deindustrialization and will be reflected in negative current accounts. We know from Aiginger (2007) that the current account positions in 2007 were among the three indicators (if not the strongest) explaining best the performance differences across countries during the crisis.

Another hypothesis connecting inequality with the current account could be derived from Kumhof et al. (2012), who argue that increases in income inequality may lead to deterioration in current accounts. They claim that inequality rises due to financial liberalization; accordingly workers try and are able to take higher debt, which results in current account deficits. This may, in particular, be true for English speaking countries. The overall correlation between our distribution index (PC-DISTR-L) with the current account balance is -0.23 for values and -0.32 for ranked data (see Table 6 ). 
Table 6. Performance ranked according to current account 2007

\begin{tabular}{|c|c|c|c|c|c|c|c|c|}
\hline & \multicolumn{2}{|c|}{ PC-Output } & \multirow{2}{*}{\multicolumn{2}{|c|}{$\frac{\text { Current account }}{\text { In percent of GDP } 2007}$}} & \multirow{2}{*}{\multicolumn{2}{|c|}{$\begin{array}{l}\text { Gini } \\
\text { ange } 2005 \text { vs. Mid } \\
1980 \mathrm{~s}\end{array}$}} & \multirow{2}{*}{\multicolumn{2}{|c|}{$\begin{array}{c}\text { Wage share } \\
\text { Change } \\
2007 \text { vs. } 1985\end{array}$}} \\
\hline & \multirow[b]{2}{*}{ Value } & \multirow[b]{2}{*}{ Rank } & & & & & & \\
\hline & & & Value & Rank & Value & Rank & Value & Rank \\
\hline Norway & 62.9 & 9 & 14.1 & 1 & 0.05 & 26 & -7.3 & 32 \\
\hline China & 97.5 & 1 & 10.8 & 2 & 0.12 & 34 & -0.3 & 16 \\
\hline Sweden & 54.9 & 19 & 9.1 & 3 & 0.04 & 20 & -10.7 & 36 \\
\hline Switzerland & 65.8 & 6 & 8.9 & 4 & -0.03 & 3 & 5.7 & 8 \\
\hline Netherlands & 59.0 & 14 & 8.5 & 5 & 0.01 & 11 & -2.1 & 23 \\
\hline Germany & 57.6 & 18 & 7.9 & 6 & 0.03 & 19 & -7.8 & 33 \\
\hline Japan & 51.3 & 26 & 4.8 & 7 & 0.02 & 12 & 1.3 & 14 \\
\hline Finland & 46.7 & 30 & 4.3 & 8 & 0.05 & 24 & -11.8 & 37 \\
\hline Belgium & 61.3 & 10 & 3.7 & 9 & 0.00 & 8 & $-\quad 1.9$ & 20 \\
\hline Austria & 59.1 & 13 & 3.4 & 10 & 0.03 & 17 & -8.0 & 34 \\
\hline Top 10 positive current account & 61.6 & 15 & 7.6 & 6 & 0.03 & 17 & -4.3 & 25 \\
\hline New Zealand & 64.4 & 8 & -8.1 & 28 & 0.06 & 28 & -5.5 & 27 \\
\hline Portugal & 58.9 & 15 & -9.8 & 29 & 0.03 & 18 & 9.3 & 3 \\
\hline Spain & 53.7 & 20 & -10.0 & 30 & -0.05 & 2 & 4.0 & 11 \\
\hline Romania & 46.4 & 31 & -13.6 & 31 & 0.12 & 35 & 4.5 & 10 \\
\hline Greece & 46.9 & 28 & -14.7 & 32 & -0.02 & 6 & 5.2 & 9 \\
\hline Lithuania & 19.8 & 35 & -15.1 & 33 & 0.12 & 36 & 7.3 & 6 \\
\hline Iceland & 42.7 & 33 & -16.4 & 34 & 0.04 & 23 & 11.5 & 2 \\
\hline Estonia & 15.7 & 36 & -17.9 & 35 & 0.11 & 33 & 1.0 & 15 \\
\hline Bulgaria & 51.1 & 27 & -22.5 & 36 & 0.05 & 25 & 2.5 & 13 \\
\hline Latvia & 0.0 & 37 & -22.5 & 37 & 0.13 & 37 & 16.9 & 1 \\
\hline Low 10 current account & 40.0 & 27 & -15.1 & 33 & 0.06 & 24 & 5.7 & 10 \\
\hline All countries used & 54.6 & 19 & -3.4 & 19 & 0.04 & 19 & -0.3 & 19 \\
\hline
\end{tabular}

Source: Wage share Eurostat (AMECO); Gini: OECD.

\section{More on robustness}

We carried out several tests on the robustness of the results. One line was to use ranks instead of values- thus reducing the impact of extreme points. A second was eliminating outsiders directly (Iceland, China, India). We calculate Principal Components separately for polarization indicators and wage shares. We combined indicators for distribution level and indicators for change in distribution and the results are rather robust.

One impression is that, in general, longer term indicators seem to have more impact on the cross country performance during the crisis than shorter term ones. The Gini is the indicator on polarization for which we have the longest period of data (up to eighties). Changes in wage shares proves significant if we started in the eighties, but not if we calculated the change towards 1995.

In general we cannot say much about causality in a cross section analysis. We lagged the distribution indicators, so that reverse causality (from crisis to distribution) should be limited. Furthermore, we know that correlations by definition connect only two variables, and do not take account of intervening forces nor reveal forces which jointly influence the two correlated variables (omitted variable bias).

An experiment to reveal the "true" impact of distribution on the depth of the crisis would be 
to use previous "good practice" regressions, which explain the country differences in the crisis and then add the distribution variable to the best practice. We took the three main explanatory forces revealed by Aiginger (2011), namely current account at the start of the crisis, growth of output in the crisis and credit growth in the crisis and added to these the level and change in distribution. Since the three variables are themselves interrelated we did this experiment for each variable separately, some of the results are shown in Table 7 for the current accounts for 2007.

Table 7. Regression output performance (PC) on distribution (PC; components) and current account balance 2007

\begin{tabular}{|c|c|c|c|c|c|c|c|c|c|c|c|c|c|c|c|c|}
\hline \multicolumn{2}{|c|}{ Current account } & \multicolumn{2}{|c|}{$\begin{array}{c}\text { Distribution } \\
\text { level }\end{array}$} & \multicolumn{2}{|c|}{$\begin{array}{c}\text { Distribution } \\
\text { change }\end{array}$} & \multicolumn{2}{|c|}{ Gini level } & \multicolumn{2}{|c|}{ Gini change } & \multicolumn{2}{|c|}{$\begin{array}{c}\text { Wage share } \\
\text { level }\end{array}$} & \multicolumn{2}{|c|}{$\begin{array}{l}\text { Wage share } \\
\text { change }\end{array}$} & \multicolumn{2}{|c|}{$\begin{array}{l}\text { Wage share } \\
\text { long change }\end{array}$} & \multirow[t]{2}{*}{$R^{2}$} \\
\hline$t b$ & $t$ & $t b$ & $t$ & $t b$ & $t$ & $t b$ & $t$ & $t b$ & $t$ & $t b$ & $t$ & $t b$ & $t$ & $t b$ & $t$ & \\
\hline 1.30 & 4.78 & 0.23 & 1.68 & & & & & & & & & & & & & 0.37 \\
\hline 1.38 & 5.03 & & & -0.36 & $-2.07 x x$ & & & & & & & & & & & 0.39 \\
\hline 1.31 & 4.84 & & & & & 82.3 & $1.79 \mathrm{x}$ & & & & & & & & & 0.38 \\
\hline 1.09 & 3.89 & & & & & & & -64.4 & -1.20 & & & & & & & 0.35 \\
\hline 1.21 & 4.46 & & & & & & & & & -0.19 & -0.91 & & & & & 0.33 \\
\hline 1.42 & 4.99 & & & & & & & & & & & 0.93 & $1.98 \mathrm{x}$ & & & 0.39 \\
\hline 1.22 & 3.74 & & & & & & & & & & & & & 0.06 & 0.15 & 0.32 \\
\hline
\end{tabular}

$\mathrm{x} \ldots$ significant at 10 percent. $\mathrm{xx} \ldots$ significant at 5 percent.

The results of this experiment are neither very strong nor robust, but some tendencies can be seen. The current account in 2007 continues to be the best predictor of the output performance during the crisis insofar as its coefficient is stable and there are some combinations with distribution indicators which improve the coefficient of determination (marginally) and where distribution variables are significant.

If we added PC-DISTR-L (the overall indicator on the distribution level) the current account is marginally significant near the $10 \%$ level, however with a coefficient indicating that inequality in 2007 - in addition to the current account surpluses - led to a marginally better performance.

If we add PC-DISTR-C (the overall change indicator) to the current account indicator, we find coefficient significance at the $5 \%$ level, indicating that decreasing inequality led to better performance.

If we do not add the overall indicator but its components, we replicate the results for Gini (positive effect of higher level of inequality in 2005, and of its decline) but it is less significant than that for the overall indicator. This is on the one hand usual for sub aggregates, on the other hand disappointing since the change in the Ginis had been significant in the correlation. For wage shares we find a (insignificant) positive impact of lower wage shares, and a positive effect of higher wage shares in the short run but not in the long run (as we found in the correlations). Thus the positive effect of lower wage shares shown in correlations seem to work via the capital account position, while the positive effect shown in the regression holds only if we take current accounts as fixed. 
All in all, these multivariate results hint that distribution and changes in distribution may have an influence in addition to current accounts. The relationship between distribution and current accounts itself is not straightforward and has to be further explored theoretically as well as empirically. We also caution against overemphasizing the tentative results from correlations.

\section{Discussion and further research direction}

In general the data show that there is no easy link between income distribution and the depth of the crisis. This negative result could have several explanations.

\subsection{Data quality}

The data on income distribution are known to be less than perfect partly because the definition of income varies so broadly across countries and sectors. This holds true for data on the polarization of incomes as well as for the ratios of wages to income. Data on personal income distribution refer partly to households, partly to individuals; they include part time work, transfers, taxes, remittances etc. Many indicators are available only for focal years (e.g. the mid nineties), and are not available annually. Some were collected according to different definitions over time and across countries, for some eastern European and emerging countries even less comparable data are available (e.g. due to informal work, a large share of agriculture). Wage shares may be adjusted for the number of workers, the number of firms, or they may include bonus elements which mirror profits instead of fixed incomes. Some authors advocate using data on the top incomes, since this was the group whose incomes rose quickest.

\subsection{Econometric methods}

The limited number of data points on distribution makes the use of sophisticated econometrics difficult. The main results are derived from correlation and robustness tests and are conducted by ranking and by eliminating outliers(Note 8). Additionally, we also use linear regressions. Panel econometric and strict tests of causality are not possible, and we have a single crisis in which country performance had been investigated. Furthermore the crisis evolved differently across countries with some countries already having regained pre-crisis levels while others still deviate from the growth path as well as from their pre-crisis level from year to year (e.g. Greece).

\subsection{Cross section deficiencies}

Usually we are inclined to believe that the impact of conflicting determinants of an event can be carved out by comparing the hierarchy of countries for a particular cause with the hierarchy of the countries for a particular the effect. If consumption affects income the changes in consumption in different countries should be strongly correlated with the changes in income, thus "proving" the impact of consumption on GDP. In a globalized world this may not be the case. Savings produced in one country may be used for investment or government spending in other countries, consumption and investment in a globalized world may be 
financed internationally.

The crisis may origin from a savings glut in China which leads to a capital abundance in the US. Distribution may limit domestic consumption, but international credit flows provide cheap credits and foster consumption and housing investment. If capital is bundled in an innovative way in new financial instruments, savings may stabilize or destabilize growth in other countries. And if credit booms come to an end, they may not do so proportionally or at the same rate in all countries but faster in countries with specific weaknesses e.g. in price competitiveness, or a foreign dominated finance system.

Thus detecting or proving the causality of a specific determinant of economic performance on the depth of the crisis by cross section evidence in a globalized world is less straightforward than for other correlations between domestic causes and effects.

\subsection{Policy reactions and fundamental strengths}

If distributional issues reduce resilience and/or growth prospects, then economic policy can react. In the run up phase to the financial crisis there were at least three reactions: first monetary policy was rather expansionary, trying to counteract signs of diminishing growth. To this one can add financial liberalization, which was thought to be efficient as well as growth promoting. Second, economic policy subsidized housing, either as policy to stabilize economic growth or as policy to enhance living standards for the poor. This happened specifically in the US, while in Europe the Monetary Union provided historically unknown low interest rates for peripheral countries. Thus the effects of changes in distribution could be neutralized, or at least deferred for some time. A third reaction has been stimulating public expenditures via sustained budget deficits and high sovereign debt (which may have been a specific policy to sustain growth or the result of the permissiveness of governments in countries like Italy, Belgium, Greece).

There is also the possibility that a given change in distribution with potentially destabilizing effects had been counteracted by economic policy. And economies that already had underlying fundamental problems may have been destabilized by a minor change in distribution, while others with a high level of price competitiveness were more able to accommodate a larger shock.

\subsection{Research directions needed}

Therefore a lot of further research is needed. One direction for this research would be to extend the data on distribution indicators, specifically the time span for polarization indicators. We should furthermore test the impact of wage shares in a larger sample of countries carefully investigating the length of time between cause and effect. The interaction between wage shares and with other variables, specifically leverage and the current account position, should be analyzed in detail.

A second direction could be to look for more crises events to be able to investigate the impact of distribution. Further research should carefully distinguish between distribution "level" and distribution "change" hypotheses. 
Thirdly research has to investigate how the impact of distribution on output performance depended on the specific policy reaction to the crisis. The reactions as well as the impact could vary according to the socioeconomic system of the countries (liberal versus coordinated countries, bank based vs. finance based; emerging countries vs. developed countries, liberalized vs. controlled financial markets).

Fourthly a specifically interesting feature could be to examine how trends between personal distribution (polarization) and functional contribution (wage vs. profit shares) relate to each other.

Last not least it may be important whether strategies addressing income distribution can effect performance differently if they are internationally coordinated or if individual countries improve their own position at the cost of others. Increasing wages by less than productivity may have a positive impact if countries thereby end up "stealing" market shares from neighbors, but may be suboptimal for growth in a larger region (or the world). The feasible country strategy may depend on size.

\section{Summary}

There are hypotheses in the literature that income inequality may impact negatively on the resilience of economies in general and that increasing income inequality was specifically an important cause of the recent financial crisis. One such hypothesis stresses the underconsumption/underinvestment consequence of lower wages or unequal wage distribution. The second focuses on the increased volatility of an economy with lower consumption (aggravated by financial liberalization). And a third group of authors analyzes the policy reactions which were implemented to stabilize economies in the short run but ended up rendering them more vulnerable in the long run.

According to the underconsumption or underinvestment hypothesis, lower wages and higher polarization reduces demand led growth and increases the gap between actual investment and investment needed ("warranted investment") for continued economic growth. According to the volatility hypothesis, lower wages and higher polarization shifts effective demand to luxury consumption and investment goods, both of which are more volatile than consumption in general. A savings glut provides a financial pool for speculation within countries or worldwide and may in combination with financial liberalization and new innovative financial products destabilize the real sector.

There are many empirical studies demonstrating that distribution shifted in the run up to this crisis (as well as in the Great Depression before that), but there is, to our knowledge, no study investigating whether the crisis had been deeper/longer in countries with a more unequal income distribution or a larger shift in this distribution. We fill this gap by using a general indicator for the depth of the recent crisis ("output performance", it aggregates different GDP indicators by Principal Component as to maximize informational values) and then similar indicators for the "level of distribution" (PC-DISTR-L) at the start of the crisis as well as for "changes in distribution" in the run up period (PC-DISTR-C). The distribution indicators 
consist of five sub-indicators, two of them relating to wage shares and three to the polarization of incomes.

The overall result is disappointing at a first glance. There is no correlation between the depth of the crisis in 37 countries and the level of distribution, nor with any of the five elements of the distribution level indicator. This is no surprise if we look at the ten countries that performed best in the crisis: some of them have low equality, while some of the worst performers had high wage shares and low polarization. There is also no correlation between the overall change in distribution and the depth of the crisis, neither for most sub-indicators nor for the overall indicator on changes.

Two features however did emerge, which deserve some attention (and look contradictionary at the first glance).

- The depth of the crisis was lower in countries in which inequality as measured by the Gini coefficient decreased. The Gini is a comprehensive indicator not just focusing at one end of income distribution and it is available for the longest period before the crisis.

- The crisis was less severe in countries in which wage share had a downward trend in the two decades prior to the crisis (2007/1985).

Both tendencies and specifically the combination of the two findings should be interpreted with care. Decreasing Gini for good performers may have been the result of a good long run performance of economies in the run up to the crisis, with decreasing unemployment and higher employment (which both usually favor low income groups). Decreasing wage shares for good performers on the other hand may be the result of fast growing countries, which had not adjusted the wages to a higher growth trend in productivity. Increasing wage shares may have been the flip side of imprudent strategies of countries which increased wages faster than productivity. There countries were probably overoptimistic due to membership of the Euro Area and experienced low interest rates. Southern European countries may have disregarded the role of new competitors in labor intensive sectors (see Aiginger - Huber - Firgo, 2012).

The results could suggest very tentatively a bifurcation hypothesis which needs to be investigated further: countries proved more stable in the financial crisis, if polarization in the incomes according to the Gini indicator decreased, but overall wages did not rise faster than productivity. Both tendencies show some relationship with the current account balance. Countries with negative current accounts before the crisis performed very badly in the crisis, and countries with positive external balances rather good (Aiginger, 2011). Increasing wages faster than productivity led to higher imports, specifically since higher income groups spend more on luxury goods. At the same time price competitiveness deteriorates lowering exports and increasing current account deficits again.

Evidence beyond the correlations, stylized facts and robustness checks tentatively support the findings; but we have still to caution that we should not jump to conclusions too early, in light of the poor data available. 
In general, the effects of distribution and of distributional changes on the financial crisis may not be detected without severe statistical problems in a cross section analysis. Several countries with high or rising inequality proved themselves to be rather resilient, while countries with low inequality and increasing wage shares faced deep and prolonged crises. In addition, the globalization of finance makes it more difficult to detect the country specific nexus between equality and resilience. Savings in one country or region can be used to stimulate demand and speculation in other countries, investment can be financed by foreign funds, capital can first flow in one direction and "suddenly" stop in the crisis. The nexus could however also be different between wage shares and personal income distribution (as indicated by our results). Further it could even be different in the short and long run, and lowering the wage share could be a resilience increasing strategy for a single country, but destabilizing if performed by many countries. Furthermore, the evidence of any link between cause and effect crucially depends on policy strategies implemented to stabilize demand. Much further research is needed to carve out any fundamental relationship between income equality and economic resilience, two issues specifically high on the policy agenda after the financial crisis.

\section{Acknowledgement}

The author acknowledges research assistance by Dagmar Guttmann and Eva Sokoll and critique by Anthony Atkinson, Ewald Walterskirchen, Sandra Steindl and Gunther Tichy. A preliminary version was published as discussion paper.

\section{References}

Acemoglu, D. (2011). Thoughts on Inequality and the Financial Crisis. Retrieved January 7 , Denver from http://economics.mit.edu/files/6348

Aiginger, K. (2009). Strengthening the resilience of an economy. Enlarging the menu of stabilisation policy to prevent another crisis. Intereconomics, October 2009, 309-316. Retrieved from http://www.ceps.eu/system/files/article/2009/10/309-316-Aiginger.pdf

Aiginger, K. (2010A). The Great Recession versus the Great Depression: Stylized Facts on Siblings That Were Given Different Foster Parents. Economics: E-Journal, 4, 2010-18.

Aiginger, K. (2010B). "Core versus periphery in the Recent Recession as compared to the Great Depression". In Lacina, L., Rozmahel, P., Rusek, A. (eds.), Financial Crisis: Institutions and Policies, November 2010, 16-38.

Aiginger, K. (2010C). "Post Crisis Policy: Some Reflections of a Keynesian Economist". In Dullien, S., Hein, E., van Treeck, T. Truger, A., (eds.), The World Economy in Crisis - The Return of Keynesianism?, Conference proceedings of the Research Network Macroeconomics and Macroeconomic Policies (FMM), 13, 245-267.

Aiginger, K. (2011). Why Growth Performance Differed across Countries in the Recent 
Crisis: the Impact of Pre-crisis Conditions, Review of Economics and Finance, 4, 35-52.

Aiginger, K., Huber, P., \& Firgo, M. (2012). Policy Options for the development of peripheral regions and countries of Europe.European Policy Brief 2, WWWforEurope, December. Retrieved from http://www.foreurope.eu/fileadmin/documents/pdf/Policybriefs/WWWforEurope_PB_n o02_D504.1.pdf

Atkinson, A. B. (1997). Bringing Income Distribution in from the Cold. Economic Journal, 107(441), 297-321.

Atkinson, A. B., \& Morelli, S. (2011). Economic Crises and Inequality. Human Development Research Paper, 06, United Nations Development Programme, Retrieved from http://papers.ssrn.com/sol3/papers.cfm?abstract_id=2351471\#\#

Atkinson, A. B., Piketty, T., \& Saez, E. (2011). Top Incomes in the Long Run of History. Journal of Economic Literature, 49(1), 3-71.

Fitoussi, J.-P., \& Saraceno, F. (2010). Inequality and Macroeconomic Performance. OFCE/Polhia, Document de travail 2010-13. Retrieved from http://www.ofce.sciences-po.fr/pdf/dtravail/WP2010-13.pdf

Fitoussi, J.-P., \& Stiglitz, J. (2009). The Ways out of the Crisis and the Building of a More Cohesive World. OFCE Science Po, Document de travail 2009-17, Paris. Retrieved from http://www.ofce.sciences-po.fr/pdf/dtravail/WP2009-17.pdf

Galbraith, J. K. (1954). The Great Crash 1929. Penguin, London.

Guger, A. (2012). Verteilung und Wirtschaftskrise, Festschrift für Günther Chaloupek anlässslich seines 65. Geburtstags, Wirtschaft und Gesellschaft, Heft 2.

Habib, B., Narayan, A., Olivieri, S., \& Sanchez-Paramo (2010). The impact of the financial crisis on poverty and income distribution: Insights from simulations in selected countries. Retrieved April 19 from http://www.voxeu.org/index.php?q=node/4905

Horn, G., Dröge, K., Sturn, S., Van Treeck, T., \& Zwiener, R. (2009). "Von der Finanzkrise zur Weltwirtschaftskrise (III). Die Rolle der Ungleichheit". IMK Report, 41, September. Retrieved from http://www.boeckler.de/pdf/p_imk_report_41_2009.pdf

Kumhof, M., \& Rancière, R. (2010). Inequality, Leverage and Crises. IMF Working Paper, WP/10/268. Retrieved from https://www.imf.org/external/pubs/ft/wp/2010/wp10268.pdf

Kumhof, M., Lebarz, C., Renciere, R., Richter, A. W., \& Throckmorton, N. A. (2012). Income Inequality and Current Account Imbalances. IMF Working Paper, WP/12/08. Retrieved from http://www.imf.org/external/pubs/ft/wp/2012/wp1208.pdf

OECD (2011). Divided We Stand: Why Inequality Keeps Rising. OECD, Paris. Retrieved from http://www.oecd.org/social/soc/dividedwestandwhyinequalitykeepsrising.htm

Onara, Ö., Stockhammer, E., \& Grafl, L. (2011). Financialisation, income distribution, and 
aggregate demand in the USA. Cambridge Journal of Economics, 35(4), 637-661.

Palley, T. (2005). The Questionable Legacy of Alan Greenspan. Challenge, 48(6), November/December, 5-19.

Palley, T. (2011). America's flawed paradigm: macroeconomic causes of the financial crisis and great recession. Empirica, 38(1), 3-17. http://dx.doi.org/10.1007/s10663-010-9142-3

Rajan, R. (2010). Fault Lines: How Hidden Fractures Still Threaten the World Economy. Princeton UP, Princeton.

Robbins, L. C. (1934). The Great Depression. Macmillan, London.

Stiglitz, J. (2009). Drunk-Driving on the US's Road to Recovery. Real Clear Politics, Retrieved January $\quad 9 \quad$ from http://www.realclearpolitics.com/articles/2009/01/drunkdriving_on_the_uss_road_t.html

Stockhammer, E. (2011). Polarisierung der Einkommensverteilung als Ursache der Finanzund Wirtschaftskrise. Wirtschaft und Gesellschaft, 37(3), 378-402.

Van Treeck, T. (2012). Did inequality cause the U.S. financial crisis? IMK Working Paper 91. http://www.boeckler.de/pdf/p_imk_wp_91_2012.pdf

\section{Copyright Disclaimer}

Copyright reserved by the author(s).

This article is an open-access article distributed under the terms and conditions of the Creative Commons Attribution license (http://creativecommons.org/licenses/by/3.0/). 